\title{
GELIAT KURIKULUM PENDIDIKAN ISLAM DI INDONESIA
}

\author{
Sahari
}

\begin{abstract}
Abstrak
Kurikulum disusun dengan tujuan untuk memudahkan penyelenggaraan pendidikan, oleh karena itu kontens kurikulum pendidikan Islam selalu berbeda-beda menurut kondisi perkembangan umat Islam, karena kaum muslimin berada di dalam lingkungan, daerah dan negeri yang berbeda-beda, Kurikulum harus didesain agar mampu menghasilkan muslim yang mampu menjadi khalifah di atas bumi. Pertimbangan dasar dalam mendesain kurikulum seperti itu ialah: Pertama, Pengembangan pendekatan keagamaan melalui semua mata pelajaran dan kegiatan. Kedua, kurikulum harus disusun sesuai dengan taraf perkembangan kemampuan pelajar. Ketiga, kurikulum haruslah disusun berdasarkan prinsip kesinambungan, berurutan dan terintegrasi.
\end{abstract}

\section{A. Pendahuluan}

Kurikulum merupakan salah satu komponen yang sangat urgen untuk terselenggaranya sebuah kegiatan pendidikan. Bahkan berhasil dan gagalnya pendidikan, tidak lepas dari sebuah kurikulum. Kurikulum salah satu komponen yang sangat menentukan sistem pendidikan, karena itu kurikulum merupakan alat untuk mencapai tujuan pendidikan dan sekaligus pedoman dalam pelaksanaan pengajaran pada semua jenis dan jenajang.

Pada awal berkemban agama Islam di Indonesia, pendidikan Islam dilaksanakan secara sederhana dalam bentuk informal, di rumah-rumah, surau-surau, dan masjidmasjid. Didikan dan ajaran Islam diberikan dengan perbuatan, contoh dan keteladanan. Walaupun diselenggarakan dengan cara yang sangat sederhana ternyata membawa hasil yang sangat baik, karena berangsur-angsur tersebarlah agama Islam keseluruh kepulauan Indonesia.

Usaha untuk menyelenggarakan pendidikan Islam menurut rencana yang teratur sebenarnya telah dimulai sejak tahun 1476. Namun perkembangan pendidikan Islam pada awalnya kurang menggembirakan, bahkan pada tahun $1882 \mathrm{M}$ pemerintah Belanda membentuk suatu Badan Khusus yang bertugas mengawasi kehidupan 
beragama dan Pendidikan Islam yang disebut Pries Terraden. Atas nasihat dari Badan inilah maka pada tahun 1905 pemerintah mengeluarkan peraturan yang isinya bahwa orang yang memberikan pengajaran (pengajian) harus minta izin terlebih dahulu. Pada tahun 1925 pemerintah mengeluarkan peraturan yang lebih ketat lagi terhadap pendidikan agama Islam yaitu bahwa tidak semua orang (Kyai) boleh memberikan pelajaran mengaji.

Jika kita melihat peraturan-peraturan pemerintah Belanda yang demikian ketat mengenai pengawasan, tekanan dan pemberantasan aktivitas Madrasah dan pondok pesantren di Indonesia, maka seolah-olah dalam tempo yang tidak lama, pendidikan Islam akan menjadi lumpuh. Akan tetapi yang dapat disaksikan dalam sejarah adalah keadaan yang sebaliknya.

Perkembangan pendidikan Islam yang semakin hari semakin pesat, menuntut praktisi pendidikan Islam membenahi sistem dan kurikulum pendidikan Islam. Tujuan pendidikan yang ingin dicapai oleh kurikulim dalam pendidikan Islam adalah sejalan dengan tujuan pendidikan Islam dan juga sesuai dengan falsafah dan pandangan hidup bangsa atau negara tersebut. Tujuan Pendidikan Islam yaitu membentuk akhlah yang mulia dalam kaitannya dengan tujuan penciptaan manusia, yaitu mengabdi kepada Allah swt.

Untuk mencapai tujuan dimaksud tidak dapat dilakukan sekaligus melainkan harus melalui tahap-tahap tertentu yang setiap tahap itu harus menuju ke sasaran yang sama, yaitu pengabdian (menyembah) kepada Allah swt.

Dalam pembahsan ini, penulis memfokuskan pada beberapa permaslahan:

1. Apa hakekat pengertian kurikulum pendidikan Islam?

2. Apa yang menjadi karakteristik kurikulum Pendidikan Islam?

3. Bagaimana Perkembangan Kurikulum Pendidikan Islam di Indonesia ? 


\section{B. Pengertian Kurikulum Pendidikan Islam}

Sebelum penulis membahas lebih jauh mengenai Perumusan Kurikulum dan Materi Pendidikan Islam. Sebaiknya penulis menjelaskan terlebih dahulu tentang apa itu kurikulun dan apa itu pendidikan Islam.

Kurikulum telah dikenal dalam dunia pendidikan, sebagai suatu istilah yang tidak asing lagi, secara etimologis, kurikulum berasal dari bahasa Yunani, yaitu 'kurir' yang artinya pelari dan curere yang berarti tempat berpacu. Jadi, istilah kurikulum berasal dari dunia olah raga pada zaman Romawi kuno di Yunani, yang mengandung pengertian suatu jarak yang harus ditempuh oleh pelari dari garis start sampai garis finis.

Berbagai definisi kurikulum telah dikemukakan oleh para pendidik, tokohtokoh ilmuan dan para sarjana dari berbagai bangsa. Ada pengertian yang sangat luas dan sebaliknya terdapat pengertian yang sempit. Perkataan kurikulum berasal dari bahasa Latin yang luas digunakan oleh bangsa Yunani. 'Curriculum' dalam bahasa Latin bermaksud 'ruang tempat pembelajaran berlaku'.

Walaupun terdapat berbagai-bagai definisi untuk kurikulum, namun hampir semua makna, atau pengertian kurikulum dari definisi-definisi itu akan kembali ke pengertian asal, yaitu satu rancangan pengajian. ${ }^{1}$

Seterusnya, Abu Bakar menjelaskan:

"Kurikulum adalah maklumat dan ilmu pengetahuan yang diajar oleh guru atau yang dipelajari oleh pelajar di sekolah atau lain-lain institusi pendidikan, dalam bentuk mata pelajaran yang terdapat dalam buku teks dalam setiap tahap pendidikannya". ${ }^{2}$

Dari pengertian ini kurikulum bermakna sebagai segala pengalaman yang diperoleh pelajar di sekolah yang mempunyai pengaruh yang baik terhadap perilaku peserta didik di bawah bimbingan pendidik untuk mencapai tujuan pendidikan.

${ }^{1}$ Sharifah Alwiah Alsagoff, Ilmu Pendidikan:Pedagogi, (Kuala Lumpur: Heinemann, 1986), h.67.

2 Abu Bakar bin Syariffuddin, Perkembangan Kurikulum Pendidikan Islam, (Bandar Seri Begawan: Universiti Brunei Darussalam, 2008), h.55. 
Akhirnya dapatlah dipahami bahawa kurikulum bukan hanya meliputi mata pelajaran dan pengalaman yang berlaku dalam kelas, malah ia meliputi semua pengalaman, aktivitas, suasana dan pengaruh yang diberikan kepada peserta didik/pelajar terhadap yang mereka kerjakan atau yang mereka jumpai di sekolah atau yang dikelolakan oleh sekolah, termasuk semua kegiatan, pengalaman budaya, seni, sosial yang dikerjakan oleh pelajar di luar jadwal waktu tetapi dikelola oleh sekolah.

Di dalam kamus bahasa Arab kurikulum sering didefinisikan sebagai jalan yang terang, atau jalan terang yang dilalui oleh manusia pada berbagai bidang kehidupannya. Seterusnya, Omar Al-Syaibani menjelaskan kurikulum dimaksudkan sebagai jalan terang yang dilalui oleh pendidik atau guru dengan orang-orang yang dididik atau dilatihnya untuk mengembangkan pengetahuan, keterampilan, dan sikap mereka. ${ }^{3}$

Nasution menjelaskan, Kurikulum dan Pengajaran. Ia menjelaskan lebih jauh mengenai kurikulum. "Macam-macam definisi yang diberikan tentang kurikulum. Lazimnya dipandang sebagai suatu rencana yang disusun untuk melancarkan proses belajar-mengajar di bawah bimbingan dan tanggung jawab sekolah atau lembaga pendidikan beserta staf pengajarnya."

Ada sejumlah ahli teori kurikulum yang berpendapat bahwa kurikulum bukan hanya meliputi semua kegiatan yang direncanakan melainkan juga peristiwa-peristiwa yang terjadi di bawah pengawasan sekolah. Jadi, selain kegiatan kulikuler yang formal juga kegiatan yang tidak formal. Yang terkhir ini sering disebut kegiatan ko-kurikuler atau ekstra-kurikuler.

Kurikulum formal meliputi.

1. Tujuan pelajaran, umum dan spesifik.

2. Bahan pelajaran yang tersusun sistematis.

3. Strategi belajar-mengajar serta kegiatan-kegiatannya.

4. Sistem evaluasi untuk mengetahui hingga mana tujuan tercapai.

3 Omar Al-Syaibani, Falsafah Pendidikan Islam, terjemahan Hasan Langgulung, (Selangor: Darul Ehsan, 1991), h.24.

${ }^{4}$ Nasution, S, Kurikulum dan Pengajaran, (cet. ke-3; Jakarta: PT Bumi Aksara, 1999), h. 5. 
Kurikulum tak formal terdiri atas kegiatan-kegiatan yang juga direncanakan, akan tetapi tidak berkaitan langsung dengan pelajaran akademis dan kelas tertentu. Kurikulum ini dipandang sebagai pelengkap kurikulum formal. Yang termasuk kurikulum tak formal ini antara lain: pertunjukan sandiwara, pertandingan antarkelas atau antarsekolah, perkumpulan hobby, pramuka, dan lainya.

Ada lagi yang harus diperhitungkan, yaitu kurikulum "tersembunyi". "Kurikulum" ini atara lain berupa "aturan tak tertulis" di kalangan siswa, misalnya "harus kompak terhadap guru" yang turut mempengaruhi suasana pengajaran dalam kelas. Kurikulum tersembunyi ini dianggap oleh kalangan tertentu tidak termasuk kurikulum karena tidak direncanakan.

Kedudukan kurikulum di sini dapat ditempatkan dalam arahan dan bimbingan juga harus bisa menduduki peran sebagai alat prediksi, yaitu alat yang dapat meramalkan masa depan. Jadi kurikulum merupakan komponen yang amat penting karena merupakan bahan-bahan ilmu pengetahuan yang diproses dalam sistem pendidikan Islam. Ia juga menjadi salah satu bagian dari bahan masukan yang mengandung fungsi sebagai alat pencapai tujuan (input Instrumental) pendidikan Islam.

Kurikulum pendidikan itu sendiri bertujuan memberi sumbangan untuk mencapai perkembangan menyeluruh dan terpadu bagi pribadi pelajar, membuka tabir tentang bakat dan kesediaan serta mengembangkannya, mengembangkan minat, kecakapan, pengetahuan, kemahiran dan sikap yang diingini; menanamkan kebiasaan, akhlak dan sikap yang penting bagi kejayaannya dalam hidup dan kemahiran untuk memperoleh pengetahuan, mengembangkan kesadaran agama, dan segala hal yang bermanfaat bagi dirinya.

Kurikulum harus didesain agar mampu menghasilkan muslim yang mampu menjadi khalifah tersebut di atas. Pertimbangan dasar dalam mendesain kurikulum seperti itu ialah: Pertama, Pengembangan pendekatan keagamaan melalui semua mata pelajaran dan kegiatan. Misalnya: Diajarkan bahwa menurut Islam, bunga uang adalah haram, sedangkan dalam kuliah ekonomi diajarkan bahwa bunga uang perlu. Maka pendekatan seperti ini membingungkan mahasiswa, dan mahasiswa cenderung 
menerima salah satu saja. Pengetahuan mereka "terbelah" dan akhirnya dapat saja tersekularisasi. Kedua, kurikulum harus disusun sesuai dengan taraf perkembangan kemampuan pelajar, sehubungan dengan itu maka prinsip ketiga, kurikulum haruslah disusun berdasarkan prinsip kesinambungan, berurutan dan terintegrasi. Kesinambungan menunjuk kepada pengulangan vertikal unsur-unsur penting dalam kurikulum; bagian-bagian penting itu tidak boleh ada bagiannya yang terputus. Berurutan (sekuen) menghendaki bahwa pengalaman baru harus bertopang pada pengalaman sebelumnya. Sedang yang dimaksud terintegrasi adalah pengalamanpengalaman dalam kurikulum itu harus berhubungan secara horisontal, pengorganisasiannya harus dilakukan sedemikian rupa sehingga siswa tidak terlalu sulit memperoleh pandangan yang menyatu tentang pengalaman-pengalaman yang telah dilaluinya. ${ }^{5}$

Mengingat dasar dan watak atau sifatnya, kurikulum pendidikan Islam dipandang sebagai cermin idealitas Islami yang tersusun dalam bentuk program yang berbentuk kurikulum itu. Jadi nantinya dapat diketahui cita-cita apakah yang hendak diwujudkan oleh proses kependidikan tersebut dengan memperhatikan program yang berbentuk kurikulum itu.

Berdasarkan keterangan di atas, maka kurikulum pendidikan Islam itu merupakan satu komponen pendidikan agama berupa alat untuk mencapai tujuan. Ini bermakna untuk mencapai tujuan pendidikan agama (pendidikan Islam) diperlukan adanya kurikulum yang sesuai dengan tujuan pendidikan Islam dan bersesuaian pula dengan tingkat usia, tingkat perkembangan kejiwaan anak dan kemampuan pelajar.

\section{Karakteristik Kurikulum Pendidikan Islam}

Kurikulum pendidikan Islam, selain harus berlandaskan pada dasar-dasar dan juga harus menganut prinsip-prinsip yang akan mewarnai kurikulum itu sendiri. Untuk mencapai tujuan pendidikan Islam yang diharapkan, maka sudah barang tentu

5 Ahmad Tafsir, Ilmu Pendidikan Dalam Perspektif Islam, (Bandung: PT. Remaja Rosdakarya, 1994), h. 70-71. 
kurikulum yang diformulasikannya pun harus mengacu pada dasar pemikiran yang Islami pula, serta dari pandangan hidup dan pandangan tentang manusia serta diarahkan pada tujuan pendidikan yang dilandasi oleh kaidah-kaidah Islami.

Di samping itu, dengan kurikulum memudahkan pula penyelenggaraan pendidikan Islam mengembangkan pembidangan keahlian dan keterampilan sesuai dengan sasaran dan tuntutan sumber daya manusia sebagai input, objek dan, subjek pendidikan Islam.

Menyadari strategisnya posisi dan fungsi kulikulum dalam penyelenggaraan pendidikan Islam, maka perumusan kurikulum pendidikan Islam di samping harus mengacu kepada prinsip-prinsip dan ciri kurikulum pada umumnya juga harus mempertimbangkan prinsip-prinsip dan nilai-nilai ajaran Islam. Dalam hal ini penulis akan memberikan beberapa contoh mengenai prinsip dan ciri kurikulum pendidikan Islam seperti berikut.

1. Kurikulum harus sejalan dengan idelitas Islam, yaitu kurikulum yang mengandung materi ilmu pengetahuan yang mampu berfungsi sebagai alat untuk mecapai tujuan kehidupan yang Islami.

2. Kurikulum yang Islami harus diproses/diaktualisasikan dengan metode yang sesuai dengan nilai-nilai yang terkandung dalam tujuan pendidikan Islam.

3. Antara kurikulum, motode, dan tujuan pendidikan Islam harus saling berkaitan (releven) dengan produk/hasil yang diinginkan

4. Cakupan dan kandungannya harus luas dan menyeluruh, sehingga mencerminkan semangat, pemikiran, dan ajaran Islam yang mendalam serta memperhatikan pengembangan dan bimbingan segala aspek pribadi siswa, intelektual, psikologi, sosial dan spiritual.

5. Selalu disesuaikan dengan bakat dan minat peserta didik.

Bila kurikulum yang didasarkan kelima prinsip tersebut dapat dirumuskan menjadi program pengajaran di sekolah, maka sudah pasti sekolah akan mampu 
menghasilkan manusia paripurna. Prinsip-prinsip inilah yang disebut dengan emerging curiculum (kurikulum yang mendorong anak didik untuk maju). ${ }^{6}$

Pendidikan Islam sebagai bagian dari pendidikan secara umum sejak masa lalu telah mengembangkan, merumuskan, dan mempedomani kurikulum dalam peyelenggaraan pendidikan Islam, walaupun susunan dan orientasinya juga mengalami perubahan dan perkembangan sesuai tututan perkembangan dunia pendidikan.

\section{Perkembangan Kurikulum Pendidikan Islam di Indonesia}

Kurikulum pendidikan Islam berbeda-beda isinya menurut kondisi perkembangan agama Islam, karena kaum muslimin berada di dalam lingkungan dan negeri yang berbeda-beda, walaupun mereka sepakat bahwa kitab suci Al-qur'an dijadikan sumber pokok ilmu-ilmu agama dan ilmu umum, Al-qur'an tetap menjadi sumber pedoman pendidikan di seluruh negara Islam, dan juga dijadikan sumber studi lainnya.

Dalam kaitan ini, Ibnu Khaldun menjelaskan tentang kesepakatan negaranegara Islam terhadap tujuan pendidikan, yakni Alquran tetap sebagai sumber pedomannya, ia menyatakan: Sesungguhnya tujuan pendidikan yang bersumberkan Alquran adalah untuk mencapai tujuan pembentukan akidah/keimanan yang mendalam dan menumbuhkan dasar-dasar akhlak al-karimah melalui jalan agama yang diturunkan untuk mendidik jiwa manusia serta menegakkan akhlak yang membangkitkan kepada perbuatan yang baik.

Sejak zaman penjajahan, bangsa Indonesia telah memiliki kepedulian terhadap pendidikan. Namun pelaksanaannya masih diwarnai oleh kepentingan politik kaum penjajah, sehingga tujuan pendidikan yang hendak dicapaipun disesuaikan dengan kepentingan mereka.

\footnotetext{
${ }^{6}$ M. Arifin, Filsafat Pendidikan Islam, (Jakarta: Bumi Aksara, 1994), h 95.
} 
Setelah bangsa Indonesia memproklamirkan kemerdekaannya, bangsa Indonesiapun menunjukan kepeduliannya terhadap pendidikan. Hal itu terbukti dengan menempatkan usaha untuk mencerdaskan kehidupan bangsa sebagai tujuan nasional bangsa Indonesia. Sebagaimana tertulis dalam pembukaan Undang-undang Dasar 1945 antara lain "mencerdaskan kehidupan bangsa". Dengan demikian maka tujuan pendidikan yang hendak dicapaipun disesuaikan dengan kepentingan bangsa Indonesia, tujuan pendidikan tersebut juga dirumuskan dalam Undang-Undang Nomor 20 tahun 2003 tentang Sistem Pendidikan Nasional (UU sisdiknas) BAB II pasal 3 yang berbunyi sebagai berikut :

Pendidikan Nasional berfungsi mengembangkan kemampuan dan membentuk watak serta peradaban bangsa yang bermartabat dalam rangka mencerdaskankehidupan bangsa, bertujuan untuk berkembangnya potensi peserta didik agar menjadi manusia yang beriman dan bertaqwa kepada Tuhan Yang Maha Esa, berakhlaq mulia, sehat, berilmu, cakap, kreatif, mandiri, dan menjadi warga negara yang demokratis serta bertanggung jawab. Agar tujuan tersebut dapat tercapai sesuai dengan yang diharapkan maka diperlukan suatu alat untuk mencapainya, yaitu "segala sesuatu yang secara langsung membantu terlaksananya tujuan pendidikan"”.

Sehubungan dengan alat pendidikan ini, Ahmad Supardi membagi alat pendidikan ke dalam dua bagian, yaitu :

1. Alat pisik, berupa segala perlengkapan pendidikan yang berupa sarana dan fasilitas dalam bentuk konkrit, seperti bangunan, alat tulis dan baca dan lain sebagainya.

2. Alat non pisik, berupa kurikulum, pendekatan, metode dan tindakan berupa hadiah dan hukuman serta uswatun hasanah atau contoh teladan yang baik dari pendidik. ${ }^{8}$ h. 96.

${ }^{7}$ Sutari Imam Barnadib, Pengantar Ilmu Pendidikan Sistematis, (FIP IKIP, Yogyakarta, 1987),

\footnotetext{
${ }^{8}$ Supardi, Ahmad, Ilmu Pendidikan Islam, (Bandung : IAIN Sunan Gunung Djati, 1988), h9.
} 
Berdasarkan pembagian alat pendidikan di atas, jelaslah bahwa salah satu dari alat pendidikan diantaranya adalah kurikulum. Sebagai alat untuk mencapai tujuan pendidikan, kurikulum harus mencerminkan falsafah sebagai pandangan hidup suatu bangsa, karena ke arah mana dan bagaimana bentuk kehidupan bangsa itu kelak, banyak ditentukan dan tergambarkan dalam kurikulum pendidikan bangsa tersebut.

Sering terjadi jika suatu negara mengalami perubahan pemerintahan, politik pemerintahan itu mempengaruhi pula bidang pendidikan yang sering mengakibatkan terjadinya perubahan kurikulum yang berlaku. Sebagai contoh sebelum Indonesia merdeka setidaknya telah terjadi dua kali perubahan kurikulum, yang pertama ketika di jajah belanda kurikulum disesuaikan dengan kepentingan politiknya. Kedua ketika dijajah Jepang kurikulum disesuaikan dengan kepentingan politiknyapula. Kemudian setelah Indonesia merdeka pra orde baru terjadi pula dua kali perubahan kurikulum, yang pertama dilakukan dengan dikeluarkannya rencana pelajaran tahun 1947 yang menggantikan seluruh sistem pendidikan kolonial, kemudian pada tahun 1952 kurikulum ini mengalami penyempurnaan dan dan diberinana rencaana Pelajaran terurai 1952. Perubahan kedua terjadi dengan dikeluarkannya rencana pendidikan tahun 1964, perubahan tersebut terjadi karena merasa perlunya peningkatan dan pengejaran segala ketertinggalan dalam ilmu pengetahuan

Saat orde barupun kurikulum mengalami beberapa kali perubahan. Perubahan pertama terjadi dengan dikeluarkannya kurikulum 1968 yang didasari oleh adanya tuntutan untuk mengadakan perubahan secara radikal pemerintahan orde lama dalam segala aspek kehidupan termasuk pendidikan. Perubahan kedua terjadi dengan diterbitkannya kurikulum tahun 1975 (disempurnakan dengan kurikulum 1976 dan 1977). Perubahan ketiga terjadi dengan diberlakukannya kurikulum tahun 1984. Dan Perubahan keempat terjadi Ketika di negara kita diberlakukan Undang-undang Sistem pendidikan Nasional (UUSPN) pada tahun 1989 beserta seperangkat peraturan pemerintah yang mengatur lebih lanjut pelaksanaan UUSPN tersebut, menyebabkan perlunya pembuatan atau penyusunan kurikulum yang sesuai dengan rumusan pasal- 
pasal yang tercantum dalam UUSPN dan peraturan pemerintahnya. Maka pada Tahun 1994 di negara kita diberlakukan kurikulum baru sesuai dengan keputusan menteri Pendidikan dan Kebudayaan Nomor 060/U/1993 tanggal 25 Februari 1993.

Perubahan dan perbaikan kurikulum itu wajar terjadi dan memang harus terjadi, karena kurikulum yang disajikan harus senantiasa sesuai dengan segala perubahan dan perkembangan yang terjadi. Hal ini sebagaimana dikemukakan oleh Subandijah bahwa: Apabila kurikulum itu dipandang sebagai alat untuk mencapai tujuan pendidikan, maka kurikulum dalam kedudukannya harus memiliki sipat anticipatori, hal ini berarti bahwa kurikulum harus dapat meramalkan kejadian di masa yang akan datang, tidak hanya melaporkan keberhasilan peserta didik. ${ }^{9}$

Seiring dengan terjadinya perubahan politik dan bergantinya rezim orde baru dan terjadinya amandemen terhadap Undang-Undang Dasar 1945 menyebabkan eksistensi Undang-Undang Nomor 2 tahun 1989 tentang Sistem Pendidikan Nasional (UUSPN) dirasakan tidak lagi memadai dan tidak lagi sesuai dengan amanat perubahan Undang-Undang Dasar 1945 tersebut dipandang perlu menyempurnakan UUSPN tersebut, dan pada tahun 2003 dengan persetujuan bersama Dewan Perwakilan Rakyat Republik Indonesia dan Presiden Republik Indonesia menetapkan Undang-Undang Nomor 20 tahun 2003 tentang Sistem Pendidikan Nasional yang kemudian lebih dikenal dengan UU SISDIKNAS. ${ }^{10}$

Sesuai dengan tuntututan UU SISDIKNAS pemerintah mengeluarkan peraturan pemerintah nomor 19 tahun 2005 tentang Standar Nasional Pendidikan yang menyebabkan kurikulum yang berlaku di sekolah adalah kurikulum yang sesuai dengan standar nasional pendidikan.

\footnotetext{
${ }^{9}$ Subandijah, Pengembangan dan Inovasi Kurikulum, (Jakarta :Raja Gravindo Persada, 1993), h.3.

${ }^{10}$ Depdiknas, Undang-Undang Nomor 20 tahun 2003, Jakarta, 2003
} 
Agar kurikulum yang digunakan di sekolah sesuai dengan standar nasional pendidikan maka Menteri Pendidikan Nasional Republik Indonesia mengeluarkan peraturan menteri pendidikan nasional nomor 22 tahun 2006 tentang standar isi yang di dalamnya memuat tentang kerangka dasar dan struktur kurikulum, beban belajar, kalender pendidikan, standar kompetensi dan kompetensi dasar. Untuk sekolah-sekolah yang berada di bawah naungan Departemen Agama tidak ketinggalan Menteri Agamapun mengeluarkan Peraturan Menteri Agama No. 2 Tahun 2008 tentang standar kompetensi lulusan dan standar isi Pendidikan Agama Islam dan Bhasa Arab di Madrasah.

Pendidikan Islam di Indonesia khususnya di madrasah masih ditemukan kesenjangan antara yang seharusnya dengan kenyataan.Di madrasah, permasalahannya adalah proporsi pendidikan agama yang dikurangi. Kurikulum madrasah semula $60 \%$ agama dan $40 \%$ umum, berubah menjadi $30 \%$ agama dan $70 \%$ umum. Terlebih ditambah dengan munculnya kurikulum madrasah 2004 yang hanya memberi proporsi lebih sedikit untuk pendidikan agama (sekitar 12\%). Problem ini semakin memicu gejolak masyarakat sekaligus mengurangi kepercayaan atas eksistensi madrasah. ${ }^{11}$

Di samping problem di atas, kurikulum pendidikan Islam yang ada saat ini pada kenyataannya masih belum sesuai dengan pertimbangan dasar dan prinsip di atas. Hal ini bisa dibuktikan dengan masih adanya mata pelajaran yang masih monoton disampaikan, sejak mulai tingkat Madrasah Ibtidaiyah (SD) sampai dengan perguruan tinggi (IAIN). ${ }^{12}$ Misalnya dalam mata pelajaran fiqh tentang thoharoh ini sudah diajarkan, namun kenapa di MTs, MAN bahkan di IAIN sendiri masih juga diajarkan sama persis seperti ketika masih di MI/SD.

11 Darmuin, Prospek Pendidikan Islam Di Indonesia: PBM-PAI Di Sekolah; Eksistensi dan Proses Belajar Mengajar Pendidikan Agama Islam, (Yogyakarta: Fakultas Tarbiyah IAIN Walisongo kerjasama dengan Pustaka Pelajar, 1998), h.82. 45.

12 Maksum, Madrasah: Sejarah \& Perkembangannya, (Jakarta: Logos Wacana Ilmu, 1999),h 
Dari berbagai uraian dan persoalan tersebut di atas, dapat diketahui bahwa kurikulum pendidikan Islam merupakan salah satu komponen yang amat penting dalam proses pendidikan Islam. Kekeliruan dalam menyusun kurikulum, akan membawa ahli didik mengemukakan ketentuan berbagai macam guna penyusunan kurikulum itu. Kurikulum yang sejalan dengan idealitas Islami adalah kurikulum yang mengandung materi (bahan) ilmu pengetahuan yang mampu berfungsi sebagai alat untuk tujuan hidup Islami.

Sedang inti dari semua pengembangan kurikulum dilihat dari sudut pandang Islami adalah kebenaran yang fundamental dan yang tidak dapat diubah. Yaitu prinsip tauhid. ${ }^{13}$ Secara garis besarnya, dalam kurikulum pendidikan Islam harus terlihat adanya unsur-unsur: 1) Ketauhidan, 2) Keagamaan, 3) Pengembangan potensi manusia sebagai khalifah Allah, 4) Pengembangan hubungan antar manusia dan 5) Pengembangan diri sebagai individu. ${ }^{14}$

\section{E. Kesimpulan}

Kurikulum pendidikan Islam adalah satu komponen pendidikan agama berupa alat untuk mencapai tujuan. Ini bermakna untuk mencapai tujuan pendidikan agama (pendidikan Islam) diperlukan adanya kurikulum yang sesuai dengan tujuan pendidikan Islam dan bersesuaian pula dengan tingkat usia, tingkat perkembangan kejiwaan anak dan kemampuan pelajar.

Karekteristik kurikulum pendidikan Islam harus sejalan dengan idelitas Islam, yaitu kurikulum yang mengandung materi ilmu pengetahuan yang mampu berfungsi sebagai alat untuk mecapai tujuan kehidupan yang Islami. Kurikulum yang Islami harus diproses/diaktualisasikan dengan metode yang sesuai dengan nilai-nilai yang

\footnotetext{
${ }^{13}$ Hamid Hasan Bilqrami dan Sayid Ali Asyrof, Konsep Universitas Islam, (Yogyakarta: PT.Tiara Wacana, 1989), h. 84.

${ }^{14}$ Jalaluddin, Usman Said, Filsafat Pendidikan, Manusia, Filsafat, dan Pendidikan, (Cet. ke-2; Jakarta: Gaya Media Pratama, 2002), 51.
} 
terkandung dalam tujuan pendidikan Islam. Cakupan dan kandungannya harus luas dan menyeluruh, sehingga mencerminkan semangat, pemikiran, dan ajaran Islam yang mendalam serta memperhatikan pengembangan dan bimbingan segala aspek pribadi siswa, intelektual, psikologi, sosial dan spiritual. Selalu disesuaikan dengan bakat dan minat peserta didik.

Perubahan dan perbaikan kurikulum memang harus terjadi, karena kurikulum yang disajikan harus senantiasa sesuai dengan segala perubahan dan perkembangan yang terjadi. Apabila kurikulum itu dipandang sebagai alat untuk mencapai tujuan pendidikan, maka kurikulum dalam kedudukannya harus memiliki sipat anticipatori, hal ini berarti bahwa kurikulum harus dapat meramalkan kejadian di masa yang akan datang, tidak hanya melaporkan keberhasilan peserta didik. tetapi dalam melakukan perbaikan kurikulum tidak boleh meninggalkan prinsip tauhid, Keagamaan, Pengembangan potensi manusia sebagai khalifah Allah, Pengembangan hubungan antar manusia dan Pengembangan diri sebagai individu. 


\section{Daftar Pustaka}

Departemen Agama, al-Qur'an dan Terjemahnya

Alsagoff, Sharifah Alwiah, Ilmu Pendidikan:Pedagogi, Kuala Lumpur: Heinemann, 1986.

Syariffuddin, Abu Bakar bin, Perkembangan Kurikulum Pendidikan Islam, Bandar Seri Begawan: Universiti Brunei Darussalam, 2008.

Al-Syaibani, Omar, Falsafah Pendidikan Islam, terjemahan Hasan Langgulung, Selangor: Darul Ehsan, 1991.

Nasution, S, Kurikulum dan Pengajaran, Cet. ke-3; Jakarta: PT Bumi Aksara, 1999.

Tafsir, Ahmad, Ilmu Pendidikan Dalam Perspektif Islam, Bandung: PT. Remaja Rosdakarya, 1994.

M. Arifin, Filsafat Pendidikan Islam, Jakarta: Bumi Aksara, 1994.

Sutari Imam Barnadib, Pengantar Ilmu Pendidikan Sistematis, FIP IKIP, Yogyakarta, 1987.

Darmuin, Prospek Pendidikan Islam Di Indonesia: PBM-PAI Di Sekolah; Eksistensi dan Proses Belajar Mengajar Pendidikan Agama Islam, Yogyakarta: Fakultas Tarbiyah IAIN Walisongo kerjasama dengan Pustaka Pelajar, 1998.

Maksum, Madrasah: Sejarah \& Perkembangannya, Jakarta: Logos Wacana Ilmu, 1999.

Hamid Hasan Bilqrami dan Sayid Ali Asyrof, Konsep Universitas Islam, Yogyakarta: PT.Tiara Wacana, 1989.

Usman Said, Jalaluddin, Filsafat Pendidikan, Manusia, Filsafat, dan Pendidikan, Cet. ke-2; Jakarta: Gaya Media Pratama, 2002.

Supardi, Ahmad, Ilmu Pendidikan Islam, IAIN Sunan Gunung Djati, Bandung 1988

Subandijah, Pengembangan dan Inovasi Kurikulum, Raja Gravindo Persada, Jakarta 1993. 